\title{
Čas křtu a výběr jména novorozence ve venkovské společnosti 19. století
}

\author{
Markéta Skořepová \\ DOI: 10.21104/CL.2018.2.04 \\ Time of Baptism and the Selection of a Newborn's \\ Name in 19th-century Rural Society
}

Abstract The essay deals with the
issue of baptismal practice in the rural
society in the 19th century based on
the quantitative analysis of 7229 entries
from the parish register of births of
the market town of Nový Rychnov and
four surrounding villages from
1800-1899. Attention is paid to the interval
between the birth and the christening of
a child, and to the popularity of names.
During the whole century, children were
baptized usually in one week after birth,
but the interval was slowly prolonging.
The day of birth often influenced the
name of the child, the custom to christen
according to the calendar was still
vital. The list of frequently given names
reflected the persisting popularity of
certain baroque saints, but also new
fashionable trends and patriotic sentiment.

Key words 19th century, baptism, godparenthood, naming practice, secularization, rural family.
Předložený příspěvek je výstupem z projektu 17-17160S Proměny kmotrovství ve venkovském prostředí v průběhu 19. století (Nový Rychnov, 1800-1899) Grantové agentury České republiky.

Contact PhDr. Markéta Skořepová, Ph.D., Historický ústav Filozofické fakulty Jihočeské univerzity v Českých Budějovicích, Branišovská 31a, 37005 České Budějovice; Muzeum Vysočiny Pelhřimov, p. o., Masarykovo náměstí 12, 39301 Pelhřimov, Czech Republic;

e-mail:m.skorepova@muzeumpe.cz, mae@centrum.cz.

Jak citovat / How to cite Skořepová, Markéta. (2018). Čas křtu a výběr jména novorozence ve venkovské společnosti 19. století. Český lid 105, 199-218. doi:http://dx.doi.org/10.21104/CL.2018.2.04 


\section{Úvod}

Křest v celém křestanském světě patřil a patří mezi nejdůležitější přechodové rituály provázející život člověka (van Gennep 1998: 124-142). V minulosti jeho význam posilovala hrozba ztráty naděje na život věčný v případě předčasného skonu dítěte (Gélis 1984) a tato obava nebyla vzhledem k přetrvávající vysoké kojenecké úmrtnosti neopodstatněná (Dokoupil - Nesládková 1987a,b; Horská 1972). Křest byl prvním krokem v socializaci novorozence, který se jím začleňoval do křestanského univerza i společenstva farnosti. V lidové tradici se stával zásadním článkem v systému rituálů a obřadů provázejících příchod na svět a byl nezbytný pro zajištění zdaru a požehnání v dalším životě jedince (Alfani - Castagnetti - Gourdon 2009; Alfani - Gourdon 2009). Ve venkovské společnosti nepřestávala být přítomnost kněze a církevního požehnání ve významných životních okamžicích důležitá minimálně po celé 19. století a pravidelně se spojovala s pověrou a magií, které podle některých autorů prokazovaly větší životnost než náboženská víra (McLeod 2000; 2007: 287296). Přestože se zavedením civilní evidence obyvatelstva roku 1868 ztratil křest povahu obligatorního kroku doprovázejícího zápis dítěte do matriky a v polovině 20. století začal být z hlediska vládní ideologie dokonce nevhodný, považovali jej mnozí rodiče nadále za nezbytnost (Navrátilová 1984).

Česká historická etnologie se problematice křtu příliš nevěnuje, přestože měl zásadní význam v životě všech společenských vrstev. K dispozici jsou kratší stati informačního charakteru otištěné například v Českém lidu na počátku 20. století, vynikající studii založenou na terénním výzkumu publikovala počátkem sedmdesátých let Marie Kovářová (1972). Spíše populárně naučnou formou přiblí̌žila starší zvyky při narození dítěte Alexandra Navrátilová (2004), která je zároveň autorkou dotazníkového šetření zkoumajícího křestní praxi v době normalizace (Navrátilová 1984). Hojnějšími výsledky k otázce křrtů nedisponuje ani historiografie, dílčí pozornost byla věnována uplatnění tridentských reforem (Grulich 2000; Melkesová 2003; Nekvapil 2011), z nejnovější doby je $\mathrm{k}$ dispozici důležitá studie o přechodových rituálech dlouhého 19. století z pohledu katolických církevních autorit (Stoklasová 2017).

Předložený text vychází z dlouholetého výzkumu rodinných a sociálních struktur farnosti a panství Nový Rychnov na Českomoravské vrchovině, který se v poslední době zaměřil na problematiku formování kmotrovských vazeb v průběhu 19. století (Skořepová 2018). Postupná analýza 7229 záznamů křestních matrik z let 1800-1899 přináší pozoruhodné poznatky o náboženském a sociálním životě neindustrializované venkovské společnosti v období všeobjímajících změn 19. věku. Patří mezi ně i postupné opouštění modelu okamžitého křtu a měnící se volba křestních jmen, kterými se článek především zabývá. Text si neklade za cíl „objevit“ převratně nové skutečnosti ohledně křestní praxe a rodinného života venkovanů, jeho přínosem oproti starším pracím je přesné chronologické a místní ukotvení zjištěných poznatků 
a zachycení časovosti naznačovaných proměn, umožněné historickodemografickou metodikou výzkumu.

Kvantitativní analýza jako nástroj pro studium duchovního života širších vrstev společnosti samozřejmě není v evropské historiografii novinkou, takřka ikonicky ji použil Michel Vovelle již v 70. letech 20. století (Vovelle 1973). Ve stejné době se kvantitativní metody začaly úspěšně uplatňovat i v českém prostředí (např́íklad Maur 2008). Kvantifikace hromadných dat excerpovaných ze sériových pramenů však zůstala omezena na studium populačního vývoje či hospodářských dějin, duchovní dějiny „českého lidu“ zůstaly pod vlivem tradiční kulturní historie či etnografie, pokud nebyly v období před rokem 1989 takřka úplně ignorovány.

Se změnou politického ovzduší se čeští badatelé k problematice náboženského života v minulosti rychle vrátili. Kvantitativní metody se však na tomto poli i přes znatelné zjednodušení úmorných pracovních postupů zdokonalenou výpočetní technikou nedokázaly prosadit, jejich místo zaujaly interpretativnější historická či kulturní antropologie (srov. například Nešpor 2006). Zahraniční výzkumy však ukazují, že odklon od „tvrdých“ analytických dat, ke kterému zejména po roce 2000 v České republice došlo, může namnoze znamenat zřeknutí se důležitých badatelských perspektiv. Př́ikladem mohou být výzkumy problematiky křestní praxe a instituce kmotrovství, které se dynamicky rozvíjejí mimo jiné v rámci mezinárodní badatelské sítě Patrinus (www.dondena.unibocconi.it/patrinus).

Teoretické i metodologické základy moderního studia dějin křtů a kmotrovství položili francouzští a italští badatelé (Alfani - Goudon - Robin 2015), pozornost je jim ale věnována také mimo historicky katolické oblasti, například v Německu (Fertig 2009) nebo ve Skandinávii (Ericsson 2000), objevují se i v jihovýchodní Evropě (Violić-Koprivec - Vekarić 2017). Většina připomenutých výzkumů se metodicky opírá o analýzy matričních záznamů, které jsou zároveň zdrojem klasických historickodemografických poznatků o populačním vývoji oblasti (nejnověji například Dalla Zuanna - Minello Piccione 2017: zejména 149-193). Zdánlivě fádní výpočty charakterizující průběh a účastníky křestních obřadů ve vybrané oblasti je možné interpretovat z hlediska proměn rodinného a sociálního života, lze je rovněž považovat za indikátor vztahu obyvatel určité lokality k náboženské víře a tradici, jejichž proměny si ve stále větší míře vynucovala postupující modernizace společnosti (Skořepová 2016a). Zásadní výhodou je možnost sledovat tyto faktory v dlouhodobých časových horizontech a pro všechny společenské vrstvy, včetně nemajetných obyvatel venkova i měst.

Zkoumaná oblast Novorychnovska leží na pomezí dnešních okresů Pelhřimov a Jihlava, v hornaté oblasti Českomoravské vrchoviny s nadmořskou výškou kolem $600 \mathrm{~m}$. n. m. Poměrně drsné klima a neúrodná půda předurčily zdejší region k pěstování brambor, ovsa a žita, velkostatek se věnoval chovu ovcí a v nájmu provozoval vedle několika mlýnů menší železný hamr, 
vinopalnu a pivovar. Významnou roli hrála domácká textilní výroba, průmysl se zde objevil až ve 20. století. Ekonomika oblasti i sociální stratifikace obyvatelstva tak zůstaly víceméně tradiční, určované nepř́liš výnosnou zemědělskou produkcí a konjunkturou protoindustriální či řemeslné výroby (Schaller 1790: 81-84; Sommer 1842: 155-160; Trajer 1862: 698-700; Hille 1895).

V rámci předkládaného výzkumu byla pozornost věnována městečku Nový Rychnov, které bylo sídlem správy stejnojmenného arcibiskupského panství i farnosti a také přirozeným hospodářským centrem oblasti, kde se koncentrovala řemeslná a protoindustriální výroba. Dále byly pro výzkum vytipovány poměrně lidnaté, zemědělsky orientované vesnice Milíčov a Hojkov a menší, původně dominikální domkářské osady Chaloupky a Dolní Hutě. Všechny čtyři vsi leží v okruhu pěti kilometrů, respektive kolem hodiny pěší chůze od městečka. V průběhu 19. století v oblasti docházelo k neustálému a poměrně výraznému nárůstu počtu obyvatelstva, stagnace a pokles se dostavily ke konci zkoumaného období. ${ }^{1}$

Lze předpokládat, že populační vývoj oblasti jen málo ovlivňovala imigrace, v druhé polovině století se spíše množil počet těch, kteří region opouštěli. S okolním světem Novorychnovsko spojila ve 40. letech 19. století silnice zbudovaná mezi Pelhřimovem a Jihlavou, roku 1888 se přiblížila železniční trat'. Oblast byla národnostně česká a obyvatelstvo se až na jednotlivce hlásilo ke katolickému vyznání. Teoretická možnost využití civilních matrik se na Novorychnovsku do konce 19. století vůbec neuplatnila (podrobněji Skořepová 2016b; 2018).

Základním pramenem pro představený výzkum křestní praxe se staly katolické matriky křtěných, ze kterých byly excerpovány všechny záznamy hlásící se k vymezené oblasti pro roky 1800-1899, přičemž časový záběr byl určen dochováním a dostupností pramene. Na jejich základě byla sestavena jmenná databáze vytvořená v programu Access, která ve své finální podobě zahrnuje 7229 záznamů, které přinesly informace o narození 3410 dívek, 3814 chlapců a pěti dětí neurčeného pohlaví. Mezi nimi bylo 194 dětí, které se narodily a zemřely, aniž dostaly jméno. Celkem v 51 př́ípadech provedla křest porodní bába bez účasti kněze.

\section{Prodleva mezi narozením a křtem}

Z křestních matrik byla do databáze přepsána data narození i křtů všech dětí a vypočítána prodleva, ke které mezi nimi došlo. Na začátku sledovaného období

1 V roce 1840 měl Nový Rychnov 1047 obyvatel, Dolní Hutě 80, Hojkov 259, Chaloupky 79, Milíčov 279; v roce 1880 žilo v Novém Rychnově 1139, v Dolních Hutích 61, v Hojkově 411, v Chaloupkách 90, v Milíčově 411 obyvatel; první sčítání lidu v Československu z roku 1921 evidovalo v Novém Rychnově 953, v Dolních Hutích 51, v Hojkově 492, v Chaloupkách 83, v Milíčově 385 obyvatel (Historický lexikon 2006: 564-658, 578-579; Statistický lexikon 1923: 53-57). 
matriky nezřídka uváděly pouze jediné datum označující křtiny, tyto případy byly přiřazeny ke křtům, jež proběhly v den narození. Křtiny uspořádané ještě téhož dne, kdy dítě přišlo na svět, lze společně s obřady vykonanými hned nazítří poté považovat za bezprostřední křty, jejichž načasování ovlivňovala v matrikách nezaznamenávaná denní či noční hodina porodu. Ambivalentní skupinu představují křty vykonané dva dny po narození, za odložené křty byly pro účely této studie považovány křtiny dětí třídenních a starších.

Etnografické i historickodemografické práce shodně uvádějí, že během raného novověku býval časový interval mezi narozením dítěte a jeho křtem velmi krátký, teprve v průběhu 19. století se začínal prodlužovat až na několik málo dnů či týdnů. S tímto tvrzením lze souhlasit, ovšem s připomenutím, že systematické propočty pro delší časový horizont dosud nebyly v českém prostředí provedeny. Požadavek okamžitého křtu byl zdůvodněn obavou ze smrti nepokřtěného dítěte, kterému by byla upřena spása. Zatímco církevní věrouka hovořila o pobytu nepokřtěných dětských duší v „limbu“, tedy v místě bez utrpení, ale také bez blaženosti, rozšiřrené pověry navíc „nekřtěňátkům“ přisuzovaly posmrtné trápení i zlovolné zásahy na zemi. Nepokřtěnému dítěti hrozilo uřknutí, jeho přítomnost byla nebezpečná celé domácnosti (Navrátilová 2004: 72-80; 296-298).

V českém církevním prostředí nebylo na rozdíl od řady evropských oblastí vydáno nařízení, které by přesně stanovovalo lhůtu, v níž měl být křest proveden. ${ }^{2}$ Doporučovala se a po většinu 19. století zřejmě víceméně i dodržovala týdenní lhůta, během které měly křtiny proběhnout (Pauly 1902: 10-11; Stoklasová 2017: 127-130). Tento chvat vylučoval přítomnost matky novorozence, která se obřadu nemohla zúčastnit ze zdravotních důvodů i kvůli rituálním omezením, vycházejícím z větší části spíše z lidové tradice než z církevních nařízení, které předepisovaly provedení očistného úvodu před prvním vstupem do kostela po ukončení šestinedělí (Navrátilová 2004: 129-140; Vlčková 2015). Obřad introductio mulieris post partum církev interpretovala jako žehnání matky, v laickém prostředí převážila představa nutnosti purifikace „nečisté“ rodičky, s níž ale nebylo nutné čekat do konce faktického šestinedělí a mohla být provedena dřive. Křtiny a úvod bylo možné spojit a zdá se, že v měštanském prostředí konce 19. století se tak skutečně dělo, dokonce i při domácích křtech (Stoklasová 2017: 140-143).

Postupné odkládání křtů o pár dnů či dokonce týdnů, jež bylo na konci 19. století jasně patrné, pokládali soudobí kritici z řad kněží za výraz nežádoucí náboženské vlažnosti. Zejména v liberální měšṫanské společnosti mohlo být odložení křtu skutečně vnímáno jako projev sebevědomí rodičů dítěte vůči

2 V Anglii měli od roku 1642 rodiče povinnost dát dítě pokřtít nejpozději druhou neděli následující po narození, ve Francii bylo roku 1698 nařízeno křtít do 24 hodin po porodu, roztříštěné italské normy se shodovaly, že by prodleva mezi narozením a křtem neměla být delší jednoho týdne (Boulton 1989; Gourdon 2006; Dalla-Zuanna - Minello - Alfani 2017). 
katolické církvi (Violić-Koprivec - Vekarić 2017: 106-107). Výzkum provedený pro pařížské a římské farnosti dokázal i jistý vliv politických změn na dodržování církevních předpisů pro načasování křtů (Gourdon 2006). Zavedenému imperativu okamžitého křtu bylo možné racionálně oponovat zdravotními důsledky, jaké mohla mít cesta do chrámu pro křehký organismus právě narozeného dítěte (Dalla Zuanna - Minello - Piccione 2017). Těm bylo možné teoreticky předejít pozváním kněze do domu a provedením křtu v domácím prostředí, v pražské arcidiecézi však proti této alternativě panovaly výhrady a navíc se zřejmě omezovala jen na lépe situované vrstvy obyvatelstva. Teprve Ordo baptismi parvulorum z roku 1969 a Kodex kanonického práva vyhlášený v roce 1983 poukázaly na ochranu zdraví dítěte i matky a oficiálně doporučily křest odložit až na dobu po jejich úplném zotavení. Tou dobou už tento trend reálně fungoval řadu desetiletí a lze předpokládat, že jej posílila medikalizace porodnictví (Alfani - Goudon - Vitali 2011: 7).

Ve srovnání se situací v evropských metropolích a bezpochyby i s dosud neprobádaným vývojem v urbanizovaných českých regionech se plánování křestních obřadů na Novorychnovsku může jevit jako velmi konzervativní. Na frekvenci křtů neměl vliv ani zničující požár novorychnovského kostela a fary v roce 1828. Pouze deset dětí za celé století bylo pokřtěno déle než po týdnu, nejdelší zaznamenaný interval činil 12 dnů. Při rozdělení sledovaného období na drobnější úseky je však patrný zřetelný a významný posun. V prvním desetiletí 19 . století bylo 98,9 \% dětí pokřtěno nejpozději den po narození, v následujícím půlstoletí se podíl bezprostředních křtů pohyboval kolem $95 \%$, v šedesátých letech natrvalo klesl pod devět desetin a po roce 1890 spadl na pouhých 44,6\% (podrobněji Skořepová 2018). V posledním sledovaném desetiletí se nejobvyklejším termínem křtin stal druhý den po narození (tedy třetí, pokud je započítán i samotný den příchodu na svět), který pro křest svého dítěte zvolila takřka třetina rodičů.

Celkem 317 dětí, které na Novorychnovsku v letech 1890-1899 přijaly první svátost s prodlevou tří a více dnů po narození, představuje jen 4,5 \% ze všech 7048 pokřtěných dětí, jedná se však o menšinu, již se vyplatí sledovat. Na úvod je možné poznamenat, že v otázce načasování křtu rodiče nečinili rozdíl mezi syny a dcerami, o tři a více dnů byly odloženy křtiny 158 dívek (4,8 \% všech narozených děvčat) a 159 chlapců ( $4,3 \%$ všech narozených hochů). Jen 26 z těchto dětí přišlo na svět v první polovině 19. století, přičemž teprve v roce 1840 byla poprvé zaznamenána prodleva sedm dnů. Změna v př́ístupu k pořádání křtin byla velmi pomalá a pozvolná, jednoznačně se projevila až v osmdesátých letech, kdy podíl křtů uskutečněných v den narození či nazítří poté klesl na „pouhých“ $66,7 \%$. Je otázkou, co tuto změnu způsobilo. Jistý vliv patrně měly společenské a politické změny, které celkově oslabily postavení katolické církve, avšak ještě v sedmdesátých letech se Novorychnovsko navzdory vzniku civilní evidence obyvatelstva a zrušení konkordátu s Vatikánem drželo ustálené zvyklosti bezprostředního křtu konaného nejpozději den po narození. 
Diskutabilní se zdá role zdravotních hledisek, která mohla rodiče přimět k tomu, aby s křtinami počkali alespoň pár dnů a nevystavovali dítě transportu do farního chrámu těsně po porodu. Absolutní i relativní většina křtů odložených o tři a více dnů se totiž týkala obyvatel Nového Rychnova, kteří měli kostel i faru doslova na dosah, naproti tomu z okolních vesnic posílali novorozence ke křtu se zpožděním méně často. ${ }^{3}$ Zejména u vzdálenějších lokalit by bylo možné předpokládat, že důležitým důvodem pro odložení cesty do kostela mohlo být nepříznivé počasí spojené s neschůdností cest. Na hornatém Novorychnovsku nehrozily například povodně, jediným omezujícím meteorologickým faktorem tedy mohla být zima, respektive srážky. Rozvržení odložených křtů podle měsíců narození dětí však nenaznačuje, že by od splnění náboženské povinnosti odrazovalo zimní počasí. Naopak v lednu a zejména v prosinci byl podíl odložených křtů vzhledem k počtu všech narozených velmi nízký. O poznání hojněji rodiče posunovali křtiny svých dětí v dubnu, srpnu a září a zcela nejčastěji v říjnu. Zdá se tedy, že důležitějším faktorem než počasí mohly být zemědělské práce a podzimní příprava usedlosti na nadcházející zimu, které časově neomezovaly jen rodiče, ale i kmotry a případné další účastníky křestního obřadu. Této hypotéze nasvědčují i dochovaná meteorologická pozorování, která v Čechách 19. století rozpoznala několik velmi chladných zim, ani v jedné z nich však na Novorychnovsku nedošlo ke koncentraci odkládaných křtů (Cílek - Svoboda - Vašků 2003: 403-406, 567-571).

Tabulka 1 Odložené křty podle měsíce narození, Novorychnovsko 1800-1899 (Zdroj SOA Třeboň, SMJK, FÚ Nový Rychnov, matriky narozených, vlastní výpočet)

\begin{tabular}{|c|c|c|c|c|c|c|c|}
\hline \multicolumn{2}{|c|}{ Měsíc narození } & leden & únor & březen & duben & květen & červen \\
\hline \multicolumn{2}{|c|}{ Všichni narození } & 728 & 641 & 630 & 556 & 646 & 538 \\
\hline \multirow{2}{*}{$\begin{array}{l}\text { křty } \\
\text { s prodlevou } \\
3 \text { a více dnů }\end{array}$} & počet & 27 & 29 & 27 & 28 & 22 & 19 \\
\hline & $\begin{array}{l}\% \text { ze všech } \\
\text { narozených }\end{array}$ & 3,7 & 4,5 & 4,3 & 5,0 & 3,4 & 3,5 \\
\hline \multicolumn{2}{|c|}{ Měsíc narození } & červenec & srpen & září & ř́jen & listopad & prosinec \\
\hline \multicolumn{2}{|c|}{ Počet narozených } & 601 & 577 & 571 & 595 & 523 & 623 \\
\hline \multirow{2}{*}{$\begin{array}{l}\text { křty } \\
\text { s prodlevou } \\
3 \text { a více dnů }\end{array}$} & počet & 24 & 29 & 28 & 41 & 24 & 19 \\
\hline & $\begin{array}{l}\% \text { ze všech } \\
\text { narozených }\end{array}$ & 4,0 & 5,0 & 4,9 & 6,9 & 4,6 & 3,1 \\
\hline
\end{tabular}

3 Z 317 dětí křtěných s prodlevou tří a více dnů pocházelo 233 z Nového Rychnova (73,5 \%), 43 z Hojkova (13,6 \%), 25 z Milíčova (7,9 \%), 10 z Chaloupek (3,2 \%) a 6 z Dolních Hutí (1,9\%). Relativní převaha odložených křtů v Novém Rychnově je zřejmá při porovnání s celkovým počtem provedených křtů v jednotlivých sídlech: Nový Rychnov se podílel 3976 (56,4 \%), Milíčov 1260 (17,9 \%), Hojkov 1196 (16,9\%), Chaloupky 349 (5,0 \%), Dolní Hutě 267 (3,8 \%) křty z celkových 7048 za období 1800-1899. 
Otázkou, kterou se zatím nepodařilo uspokojivě zodpovědět ani speciálně zaměřeným výzkumům, je příčina doložené souvislosti brzkých křtů a novorozenecké úmrtnosti, tj. mortality dětí mladších jednoho měsíce či přesněji 28 dnů. Není totiž možné rozhodnout, zda slabé a neduživé děti nechávali jejich rodiče bezodkladně pokřtít proto, aby se tváří v tvář hrozící fyzické smrti podařilo zachránit alespoň jejich duše, nebo zda naopak uspěchané přenášení právě narozených dětí do kostela, způsobující př́liš velký nápor na křehkou imunitu novorozenců, nebylo vlastní příčinnou četných úmrtí. Posuzováním této problematiky v případě Novorychnovska by mohlo dojít k závažným zkreslením: dohledaná data úmrtí dětí zaznamenaných v křestních matrikách pro první polovinu 19. století zřejmě nejsou úplná a ani v př́ípadě následujících desetiletí nelze vzhledem k nízkému počtu odložených křtů hovořit o hodnověrném, reprezentativním vzorku. $V$ každém případě však nebyla vysledována souvislost mezi odkládáním křtů a četností novorozeneckých úmrtí podle měsíce narození. ${ }^{4}$

K prokazatelnému a trvalému snížení kojenecké úmrtnosti na Novorychnovsku došlo až v posledních dvou desetiletích 19. století, kdy podíl dětí, jež nepřežily první rok života, klesl k hodnotě $200 \%$, zatímco ještě v sedmdesátých letech dosahoval 250,3 \%o a v šedesátých 233,2 \%o. Stále se však jednalo o celou pětinu dětí, kterým nebylo souzeno, aby se dožily prvních narozenin, a nelze předpokládat, že by tehdejší rodiče toto nesporné zlepšení mortalitních poměrů „uklidnilo“ve starostech o život a spásu jejich ratolestí. Pokrok v zdravotní péči a osvětě jim možná dovolil posunout křtiny zdravého dítěte o den či dva, rozhodně však nepřipouštěl, aby riskovali př́lišné otálení.

V souvislosti s křestními obřady a výběrem kmotrů v závěru 19. století byla vyslovena myšlenka o familiarizaci a zintimnění tohoto rituálu, který opouštěl přísně církevní rovinu a stával se rodinnou slavností. Vedle přijetí první svátosti a začlenění dítěte do společenstva věřících se stále více prosazovala světská rovina přivítání nové ratolesti, které mohlo být více či méně spojeno s reprezentací rodiny i širšího př́ibuzenstva (Navrátilová 2004: 72-88, 124-128).

Dokladem příklonu k slavnostnějšímu, reprezentativnějšímu či jen klidnějšímu pořádání křtin je jejich přesunování na neděle nebo jiné významné dny církevního kalendáře, kdy bylo možné počítat s přítomností většího

4 Do měsíce po narození zemřelo 76 (10,4 \%) ze 728 dětí narozených v lednu, 80 (12,5 \%) ze 641 narozených v únoru, 65 (10,3 \%) ze 630 narozených v březnu, 56 (10,1%) z 556 narozených v dubnu, 65 (10,1 \%) ze 646 narozených v květnu, 60 (11,2 \%) ze 638 narozených v červnu, 62 (10,3 \%) ze 601 narozených v červenci, 68 (11,8 \%) z 577 narozených v srpnu, 53 (9,3 \%) z 571 narozených v září, 63 (10,6 \%) z 595 narozených v říjnu, 54 (10,3%) z 523 narozených v listopadu a $85(13,6 \%)$ ze 623 dětí narozených v prosinci. Celkem první měsíc života nepřežilo 787 (10,9 \%) ze zkoumaných 7229 dětí narozených na Novorychnovsku v letech 1800-1899. 
počtu věřících v chrámu a nabízela se i možnost využít svátečního, nepracovního dne k uspořádání drobné domácí oslavy spojené s přizváním hostů, která bývala původně spojována spíše s úvodem matky na konci šestinedělí (Bělík 1946). Dokladem je 126 křtů dětí, jež byly pokřtěny čtvrtý či některý následující den po svém narození, u nichž bylo dohledáno týdenní datum. Celkem $53 \mathrm{z}$ nich se odehrálo v neděli, dalších pět bylo přesunuto na některý mariánský svátek, po třech připadlo na den svatých apoštolů Petra a Pavla a Mládátek betlémských, dvakrát se křtiny spojily se svátkem zemského patrona sv. Vojtěcha, objevily se také Hromnice, Pondělí velikonoční, Povýšení sv. Kříže, svátek Všech svatých.

Většina těchto svátečních křtů ( 56 z celkových 70 ) se týkala dětí narozených přímo v městečku Nový Rychnov, lze tedy takřka vyloučit vysvětlení, že se účastníci křestního obřadu například z časových důvodů snažili spojit křtiny s běžnou nedělní cestou do kostela. Převaha nedělí a svátků mezi křestními dny v rodinách, které se rozhodly oproti tradičnímu zvyku nepokřtít dítě okamžitě po narození, svědčí o tom, že sílící trend odkládání křtů nelze jednostranně interpretovat jako doklad náboženské vlažnosti. Zároveň je ale třeba předpokládat, že koncem století mohlo být (byt' nepatrné) odložení křtin pro „moderněji“ založené otce a matky vyjádřením jistého odstupu od církevních rituálů nebo od uvažování prostých vesnických sousedů, kteří s provedením křestního obřadu svých dětí spěchali a přisuzovali mu až magický účinek.

\section{Volba křestních jmen}

O náboženské a sociální situaci sledované oblasti může mnohé vypovědět i charakteristika udílených křestních jmen. Onomastika se v českém prostředí stala oblíbeným tématem historického výzkumu především v 60. a 70. letech minulého století (např́íklad Hofmann 1968; Mužík 1979), aktuálně se orientuje spíše na současnost (Knappová 2017). Odlišný pohled mohou opět nabídnout například francouzské výzkumy, které dokládají historiograficky významnou výpovědní hodnotu, kterou s sebou analyticky uchopené zkoumání udílených křestních jmen nese (Dupâquier 1981; Arrizabalaga 2016; Coulmont 2016; Quemener 2017).

Výběr křestních jmen významným způsobem ovlivňovala církevní nařízení a v konkrétní praxi i přístup jednotlivých kněží. Udílení jmen mimo římské martyrologium výslovně zakázal tridentský koncil, před nekřestanskými jmény varovaly pastorační příručky ještě na konci 19. století, kdy se svých práv začaly domáhat nejrůznější světské módní vlivy (Stoklasová 2017: 131). V prostředí českého venkova se od 18. století prosazovala jména nově kanonizovaných potridentských svatých, jejichž nositeli se stávali i habsburští panovníci a po nich další „vrchnosti“ ovlivňující životy a vkus venkovanů (Ducreux 2006: 166-173). Popularitu si ze staršího období udržela jména jako Anna, 
Jan, Václav, ovšem řada dříve oblíbených patronů z řad apoštolů či raně křestanských mučedníků byla víceméně vytlačena. Od konce 18. století se také výrazněji rozšírilo přechylování původně mužských jmen do ženské podoby a řada dívek byla pokřrtěna jmény Josefa, Františka či Antonie (např́íklad Knappová 1978).

Drtivá většina novorozenců na Novorychnovsku v 19. století dostávala pouze jediné, tradiční jméno některého barokního světce či zemského patrona. Zdvojené jméno se objevilo u 163 dětí, tři křestní jména obdrželo deset novorozenců, v roce 1870 v Novém Rychnově přišla na svět dcera hostinského z Ládví Marie Apolonia Amalia Franciska, její rodina zde však pobývala jen krátce. Vyhodnocení užívaných jmen, která se objevují v novorychnovských křestních matrikách v letech 1800-1899, přineslo očekávatelné závěry. Více než polovina dívek se dělila o jména Marie/ Mariana, Anna, Kateřina a přes dvě třetiny chlapců nosily jména Josef, Jan, František či Václav. I zde je však možné vysledovat pozvolnou a zajímavou proměnu.

Pro následující analýzu bylo vybráno 3232 dívek a 3629 chlapců, kteří u křtu obdrželi jen jediné jméno. Celkem bylo při křtech uděleno 42 ženských a 57 mužských jmen. U chlapců i dívek se snadno vyčlenily tři skupiny podle četnosti, které lze pro zjednodušení označit jako oblíbená, běžná či ojedinělá jména. Do kategorie oblíbených jmen, která nad křtitelnicí zazněla více než sedmdesátkrát a jejich nositelé představovali v souhrnu více než $2 \%$, bylo shodně včleněno devět dívčích a devět chlapeckých jmen. Mezi méně častá, přesto poměrně hojná jména s více než deseti nositeli se zařadilo 13 ženských jmen, o které se podělilo 325 dívek, ${ }^{5}$ a 8 jmen mužských s celkem 166 nositeli. ${ }^{6}$ Jako ojedinělá lze hodnotit jména, která byla udělena méně než desetkrát, jednalo se o 20 ženských jmen s celkem 70 nositelkami a 39 jmen, která se objevila v křestních záznamech 113 chlapců. Pro obě pohlaví platí, že výskyt méně běžných a ojedinělých jmen stoupal od poloviny století. 
Tabulka 2 Nejobvyklejší ženská jména, Novorychnovsko 1800-1899

(Zdroj SOA Třeboň, SMJK, FÚ Nový Rychnov, matriky narozených, vlastní výpočet)

\begin{tabular}{|c|c|c|c|c|c|c|c|c|c|c|c|}
\hline Rok narození & $\frac{\sqrt{\frac{\pi}{2}} \frac{\frac{c}{\pi}}{\frac{\pi}{L}}}{\sum^{\frac{\pi}{2}}}$ & $\begin{array}{l}\frac{\sigma}{c} \\
\frac{c}{<}\end{array}$ & 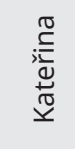 & 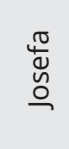 & 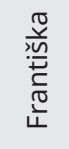 & $\begin{array}{l}\frac{\omega}{n} \\
\frac{\alpha}{\omega} \\
\leftarrow\end{array}$ & 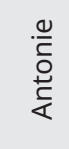 & $\frac{\substack{\frac{\pi}{N} \\
\frac{1}{2}}}{\frac{C}{4}}$ & 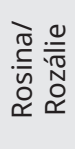 & $\stackrel{\Perp}{\cong}$ & $\begin{array}{l}\text { Všechny } \\
\text { dívky } \\
\text { s jediným } \\
\text { jménem }\end{array}$ \\
\hline 1800-1809 & 50 & 27 & 53 & 5 & 4 & 35 & 0 & 0 & 20 & 40 & 234 \\
\hline 1810-1819 & 61 & 73 & 76 & 12 & 8 & 50 & 0 & 0 & 6 & 29 & 315 \\
\hline $1820-1829$ & 82 & 76 & 54 & 14 & 20 & 34 & 11 & 0 & 11 & 29 & 332 \\
\hline 1830-1839 & 59 & 66 & 34 & 25 & 21 & 19 & 13 & 0 & 13 & 27 & 276 \\
\hline 1840-1849 & 83 & 54 & 55 & 29 & 28 & 17 & 21 & 0 & 15 & 28 & 330 \\
\hline $1850-1859$ & 125 & 69 & 26 & 42 & 23 & 21 & 22 & 1 & 8 & 40 & 378 \\
\hline $1860-1869$ & 115 & 67 & 35 & 45 & 30 & 3 & 13 & 2 & 2 & 37 & 349 \\
\hline 1870-1879 & 103 & 50 & 37 & 44 & 20 & 4 & 10 & 9 & 1 & 55 & 333 \\
\hline 1880-1889 & 124 & 30 & 22 & 42 & 43 & 8 & 8 & 27 & 1 & 48 & 353 \\
\hline 1890-1899 & 97 & 54 & 11 & 24 & 33 & 1 & 7 & 44 & 0 & 62 & 332 \\
\hline celkem & 899 & 566 & 403 & 282 & 230 & 192 & 105 & 83 & 77 & 395 & 3232 \\
\hline$\%$ & 27,8 & 17,5 & 12,5 & 8,7 & 7,1 & 5,9 & 3,2 & 2,6 & 2,4 & 12,2 & 100 \\
\hline
\end{tabular}

Tabulka 3 Nejobvyklejší mužská jména, Novorychnovsko 1800-1899

(Zdroj SOA Třeboň, SMJK, FÚ Nový Rychnov, matriky narozených, vlastní výpočet)

\begin{tabular}{|c|c|c|c|c|c|c|c|c|c|c|c|}
\hline Rok narození & 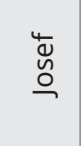 & 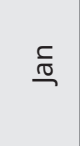 & 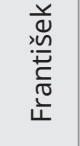 & $\begin{array}{l}\frac{\pi}{4} \\
\frac{\pi}{\pi} \\
\text { > }\end{array}$ & $\begin{array}{l}\cong \\
\frac{5}{0} \\
\frac{1}{<}\end{array}$ & 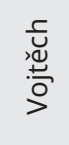 & $\frac{. \frac{C}{t}}{\sum^{\pi}}$ & $\begin{array}{l}\bar{\Phi} \\
\frac{\Phi}{\widetilde{\pi}}\end{array}$ & 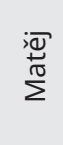 & $\stackrel{\text { 光 }}{\Xi}$ & $\begin{array}{l}\text { Všichni } \\
\text { chlapci } \\
\text { s jediným } \\
\text { jménem }\end{array}$ \\
\hline 1800-1809 & 54 & 61 & 24 & 32 & 1 & 18 & 31 & 14 & 18 & 29 & 282 \\
\hline $1810-1819$ & 74 & 69 & 41 & 56 & 2 & 8 & 25 & 3 & 13 & 26 & 317 \\
\hline $1820-1829$ & 103 & 81 & 42 & 57 & 9 & 17 & 17 & 10 & 12 & 22 & 370 \\
\hline 1830-1839 & 76 & 77 & 42 & 39 & 20 & 14 & 7 & 11 & 11 & 24 & 321 \\
\hline $1840-1849$ & 103 & 82 & 58 & 58 & 34 & 19 & 13 & 8 & 6 & 13 & 394 \\
\hline $1850-1859$ & 127 & 80 & 57 & 44 & 36 & 16 & 9 & 13 & 13 & 20 & 415 \\
\hline 1860-1869 & 112 & 70 & 77 & 44 & 47 & 11 & 5 & 15 & 6 & 34 & 421 \\
\hline 1870-1879 & 112 & 58 & 74 & 52 & 45 & 8 & 2 & 10 & 3 & 36 & 400 \\
\hline 1880-1889 & 104 & 40 & 81 & 49 & 38 & 5 & 2 & 7 & 3 & 39 & 368 \\
\hline 1890-1899 & 77 & 42 & 96 & 44 & 19 & 3 & 2 & 20 & 2 & 36 & 341 \\
\hline Celkem & 942 & 660 & 592 & 475 & 251 & 119 & 113 & 111 & 87 & 279 & 3629 \\
\hline$\%$ z & 26,0 & 18,2 & 16,3 & 13,1 & 6,9 & 3,3 & 3,1 & 3,0 & 2,4 & 7,7 & 100 \\
\hline
\end{tabular}


Krátkodobě se měnící četnost výskytu u nejoblíbenějších jmen nemusí svědčit o proměnách jejich popularity, může být spíše důsledkem početnosti tehdejších rodin a odrazem populačních vln, kdy dříve narozené děti „vyčerpaly“ nejvíce žádoucí pojmenování a teprve pro jejich mladší sourozence bylo jméno skutečně „vybíráno“. U dívek po celé 19. století nezakolísala popularita jména Marie/Mariana (obě varianty byly užívány souběžně), jehož nositelky v některých obdobích představovaly i třetinu křtěných dívek. Podobné oblibě se jako patronka těšila sv. Anna. Kontinuální pokles byl zaznamenán u jmen Kateřina a Teresie, která ještě na počátku 19. století konkurovala Marii i Anně, avšak ke konci sledovaného období se objevovala poměrně zřídka; jméno Rosina/Rozálie takřka vymizelo. Sílící obliba překloněných jmen Josefa, Františka a Antonie odpovídala popularitě, které se těšily jejich mužské vzory; tento model se ale neprosadil u Johany, naopak Petronila byla pětkrát častější než Petr.

Mezi mužskými jmény se jako nejstabilnější projevili Josef a Václav, částečně poklesla popularita Jana, kterého v poslední třetině 19. století předběhl František, nárůstu obliby se dočkal také Antonín. Naopak dříve hojná jména jako Matěj/Matouš, Martin či Vojtěch, jejichž nositelé po roce 1800 dohromady představovali takřka čtvrtinu všech novorozených chlapců, se ke konci 19. století takřka neužívala, vytlačila je nová módní jména jako Alois či Eduard.

Nepřehlédnutelným rysem matričních záznamů starších období je kumulace udílených křestních jmen v době svátku toho kterého patrona, užíval se výrok, že dítě si jméno „přineslo“. Některé starší studie vybírání jmen podle kalendáře připisovaly jisté zlovolnosti kněží, díky kterým se křtěncům dostávalo i velmi neobvyklých jmen polozapomenutých světců, často měly být obětí tohoto zvyku nemanželské děti (Navrátilová 2004: 29). Zopakovat lze také tvrzení Františka Jílka, podle kterého měli starší sourozenci dostávat jména po kmotrech a po předcích a nejmladší si jméno měli „přinášet“ (Jílek 1961: 197).

Pojmenovávání podle kalendáře bylo po celé 19. století časté i na Novorychnovsku, týkalo se však výhradně jen oblíbených svatých patronů. Pro časové sledování tohoto jevu byly vybrány trojice mužských a ženských jmen, která patřila k nejoblíbenějším, ale jejich svátek v církevním kalendáři připadal pouze na jediné, charakteristické datum, přednost přitom dostala jména umístěná v kalendáři ke konci měsíce. Porovnávána byla data narozenin a jmenin všech dětí pokřtěných jmény Josef (19. března), Václav (28. září), Vojtěch (23. dubna), Anna (26. července), Kateřina (25. listopadu) a Josefa (19. března). Upuštěno bylo od sledování dat narození dětí se jmény Marie, Jan a František, která se během roku v kalendáři objevovala několikrát, přičemž v matrikách odkaz na konkrétního světce obvykle chyběl.

Zjištěné výsledky jsou srovnatelné pro obě pohlaví: čtvrtina Josefư, Václavů a Vojtěchů se narodila v měsíci svátku svého patrona, totéž platilo pro pětinu Anen, Kateřin a Josefek, přičemž podíl dětí pojmenovaných podle kalendáře 
v průběhu století sice kolísal, ale nelze hovořit o jeho jednoznačném, výrazném poklesu. Rozbor matrik také potvrdil preferování zvyku nepojmenovávat „pozpátku“, bylo lépe mít v daném kalendářním roce nejprve narozeniny a pak teprve jmeniny (Kovářová 1972: 210). V měsíci následujícím po svátku daného patrona se totiž frekvence výskytu jeho jména v matrikách snižovala na úroveň srovnatelnou se zbytkem roku.

Tabulka 4 Podíl nositelů oblíbených jmen narozených v měsíci svátku svého patrona (Zdroj SOA Třeboň, SMJK, FÚ Nový Rychnov, matriky narozených, vlastní výpočet)

\begin{tabular}{|c|c|c|c|c|c|c|}
\hline \multirow{3}{*}{ Rok narození } & \multicolumn{3}{|c|}{ Josef + Václav + Vojtěch } & \multicolumn{3}{|c|}{ Anna + Kateřina + Josefa } \\
\hline & \multirow{2}{*}{$\begin{array}{l}\text { všichni } \\
\text { narození }\end{array}$} & \multicolumn{2}{|c|}{ narození v měsíci svátku } & \multirow{2}{*}{$\begin{array}{l}\text { všechny } \\
\text { narozené }\end{array}$} & \multicolumn{2}{|c|}{$\begin{array}{c}\text { narozené v měsíci } \\
\text { svátku }\end{array}$} \\
\hline & & počet & $\%$ & & počet & $\%$ \\
\hline 1800-1809 & 104 & 37 & 35,6 & 85 & 13 & 15,3 \\
\hline 1810-1819 & 138 & 40 & 28,9 & 161 & 29 & 18,0 \\
\hline $1820-1829$ & 177 & 38 & 21,5 & 144 & 44 & 30,6 \\
\hline 1830-1839 & 129 & 31 & 24,0 & 125 & 30 & 24,0 \\
\hline 1840-1849 & 180 & 41 & 22,8 & 138 & 24 & 17,4 \\
\hline 1850-1859 & 187 & 36 & 19,3 & 137 & 39 & 28,5 \\
\hline 1860-1869 & 167 & 45 & 26,9 & 147 & 29 & 19,7 \\
\hline 1870-1879 & 172 & 40 & 23,3 & 131 & 23 & 17,6 \\
\hline 1880-1889 & 158 & 34 & 21,5 & 94 & 24 & 25,5 \\
\hline 1890-1899 & 124 & 27 & 21,8 & 89 & 17 & 19,1 \\
\hline Celkem & 1536 & 369 & 24,0 & 1251 & 272 & 21,7 \\
\hline
\end{tabular}

V měsíci svátku svého patrona či patronky se narodilo 171 z 942 Josefů (18,1 \%), 160 z 475 Václavů (33,7 \%), 38 ze 119 Vojtěchů (31,9 \%), 105 z 566 Anen (18,5 \%), 95 z 403 Kateřin (23,5 \%) a 72 z 282 Josefek (25,5 \%). Poměrně malé zastoupení jmen Josef mezi chlapci narozenými v březnu a Anna mezi dívkami, které přišly na svět v červenci, lze přičíst mimořádné oblibě těchto jmen, která bývala v řadě rodin udělována přednostně prvorozeným či druhorozeným dětem daného pohlaví.

Řada výzkumů uvádí, že cti pojmenovat novorozence se tradičně dostávalo křestním kmotrům, kteří měli rovněž právo dítěti předat své vlastní jméno (Stoklasová 2017: 113; zde i další literatura). Pokřrtění novorozence jménem kmotra či kmotry bylo doloženo řadou starších výzkumů pro různé oblasti Čech (například Hofmann 1968; Mužík 1979), ještě častější mělo být ve Francii (Quemener 2017). Na Novorychnovsku 19. století bylo obvyklé, že sourozenci měli totožného kmotra i kmotru, jejichž jména se samozřejmě nemohla u dětí v jedné rodině opakovat, ačkoli bylo běžné užít téhož jména v případě, že starší 
dítě předčasně zemřelo (Skořepová 2016c). Mimo kmotrů bylo zvykem vzdát pojmenováním potomka čest také prarodičům, postupně se zejména v mužské linii začala jména generačně předávat $\mathrm{z}$ otce na syna.

Vzhledem k četnosti nejoblíbenějších jmen je však u mnoha případů nemožné rozhodnout, po kom bylo konkrétní dítě pojmenováno, protože velmi často se jména rodičů, prarodičů a kmotrů shodovala. Jako extrémní příklady mohou posloužit Marie Kratochvílová narozená v roce 1899 v Novém Rychnově, která se jmenovala stejně jako její matka, kmotra i obě babičky, nebo o generaci starší Josef Daněk z Chaloupek narozený roku 1872, který měl mezi nejbližšími mužskými předky pouze nositele shodného jména a stejně se jmenoval i jeho kmotr. Připomenout je třeba i výše popsané udělování jmen podle kalendáře, které bylo zřejmě preferováno v případě, že dítě přišlo na svět v době blí̌zícího se svátku oblíbeného patrona či patronky.

Pro sledování předávání jmen mezi biologickými či duchovními příbuznými proto byla vybrána jména, v jejichž př́ipadě se počet nositelů pohyboval v řádu několika desítek a jen zřídka u nich docházelo k výše nastíněným shodám. Z osmi běžných mužských jmen se jasně vydělila tři, která se nově objevila v druhé polovině 19. století a neměla žádnou oporu ve starší generaci: Alois, Eduard a Rudolf. Podobně bylo pouze jednou zděděno jméno Petr, které dal hojkovský domkáŕ Petr Záboj v roce 1881 svému nejstaršímu synovi. Také další tradiční, byt' v daném období méně častá jména se u mužů předávala spíše v pokrevní linii. Z 37 novorozených nositelů jména Jakub bylo po někom z rodiny pokřtěno 12 chlapců, čtyřri po sobě pojmenoval kmotr, u dvou hochů se shodovalo jméno kmotra a dědečka. Podobně z 29 Tomášů tři dostali jméno svého kmotra, pět je zdědilo po otci nebo dědečkovi, jeden chlapec se jmenoval stejně jako kmotr i děd. Jméno Jiří z celkových 20 případů předali třikrát kmotři a pětkrát nejbližší příbuzní. Nepř́liš typické jméno Ignác/Hynek se rozšířilo na deset nositelů zásluhou sládka Ignáce Kordy, který je předal třem ze svých osmi kmotřenců, další čtyři chlapci (včetně Ignáce Kordy mladšího) byli takto pojmenováni po otci.

Z pestřejšího výběru „běžných“ dívčích jmen bylo pro obdobnou analýzu zvoleno osm, která svou charakteristikou i počtem nositelek alespoň zhruba odpovídala předcházejícímu maskulinnímu vzorku. Děděna nebyla poměrně hojná jména Albína a Kristina, která se rozšířila v druhé polovině 19. století natolik, že dosáhla celkového počtu 34, respektive 30 nositelek. Obě byla předána pouze jednou, a to kmotrou, stejně tomu bylo i v př́ípadě Evy, která se za celé století průběžně objevila osmnáctkrát. Časté mezigenerační předání jména je možné vysledovat u Alžběty (z 21 novorozených děvčátek sedm pojmenovala kmotra, dvě matka a jedno babička), Johany (z 16 nositelek tohoto jména se čtyři jmenovaly po kmotře a dvě po matce) nebo Veroniky (sedmi dívkám z 26 dala jméno kmotra, jedné babička a jedné matka s babičkou).

Podobně je možné pokračovat u jmen Barbora a Helena, která lze zároveň použít jako př́íklad předávání jmen „prestižních“ kmotrů. Jméno Helena 
celkem obdrželo 21 děvčat, $z$ nichž sedm pojmenovala kmotra a dvě matka. Na Novorychnovsku se rozšśřilo na samém počátku 19. století, kdy v čele zdejšího vrchnostenského úřadu stál direktor Josef Soukup, jehož manželka Helena byla v letech 1800-1802 kmotrou sedmi dětí, z toho čtyř dívek, kterým dala své jméno. Jedna $\mathrm{z}$ nich po letech porodila dceru, kterou pojmenovala po sobě a své dávno zesnulé kmotře. Svatou Barboru dostalo za patronku 24 dívek, z toho jedna se jmenovala po matce, čtyři po babičce, dalším 11 dala jméno kmotra. V sedmi případech touto kmotrou byla Barbora Kordová, žena výše zmíněného sládka Ignáce Kordy, která v letech 1818-1826 asistovala u křtin deseti dívek, z nichž pouze tři se nejmenovaly po ní - všechny ovšem měly starší sestru Barboru, kterou paní Kordová odnesla ke křtu a pojmenovala o nějaký čas dříve.

Zajímavou otázku představuje možnost předání jména otce či kmotra v překloněné podobě dceři či kmotřence. Jako nejvhodnější pro její zodpovězení se zdá jméno Antonie, nebot jména Josef/Josefa a František/Františka byla v mužské i ženské variantě natolik rozšířená a oblíbená, že lze jen těžko usuzovat, proč nebo po kom je to které dítě dostalo. Antonie se na Novorychnovsku začaly objevovat ve 20 . letech 19 . století, jméno se rozšířilo zásluhou mlynáŕky Antonie Točíkové, která je mezi lety 1826-1854 předala svým osmi kmotřenkám a dvěma vnučkám. Ze všech 105 Antonií narozených v letech 18001899 pak mělo deset společné jméno s kmotrou, dvě s matkou, čtyři s babičkou, další tři dívky ale mohly být pojmenovány po kmotrovi a sedm po otci.

Ačkoli z několika uvedených případů není možné vyvozovat dalekosáhlé závěry, zdá se, že v mužské linii se objevovala větší tendence k předávání rodových jmen, naproti tomu ženy zřejmě déle a pečlivěji udržovaly zvyk stvrdit kmotrovský závazek předáním jména. Stojí za povšimnutí, že kmotři a kmotry předávali svá jména a patrony víceméně jen v průběhu první poloviny 19. století. Ačkoli byl tento zvyk v ženské linii duchovního příbuzenství evidentně silnější, objevily se u nositelů běžných jmen po roce 1850 pouze čtyři křty, při kterých děvče dostalo jméno své kmotry. Mezi chlapci došlo $\mathrm{k}$ jedinému pozdějšímu případu v roce 1862, ale dárcem jména Tomáše Popelky byli zároveň kmotr i dědeček.

Volba jména dítěte mohla mít v některých případech výrazně reprezentativní a distinktivní charakter. Vždy se odlišovali potomci místní honorace, například zaměstnanců vrchnosti, kteří nezřídka dostávali dvě až tři jména a často byli pojmenováni mimo obvyklou paletu výběru, někdy s použitím němčiny, která se u běžné populace nevyskytovala (Adolf, Henrietta). Jejich jména někdy pronikala do širších vrstev prostřednictvím kmotrovství, jak bylo ukázáno na příkladu manželů Kordových. V šedesátých letech se ale na Novorychnovsku i u „řadových občanů“ občas začínají objevovat slovanská jména, která byla v průběhu novověku víceméně zapomenuta a oživení se dočkala až v souvislosti se snahami národních buditelů (Knappová 1978: 17-18). 
Nešlo o nijak častou záležitost, „slovansky“ bylo pojmenováno 33 dívek a 43 chlapců. Rozdíl mezi „moderně“ pojmenovanými hochy a děvčaty není jen v počtu. Zatímco nová mužská jména se dovolávala slovanské tradice nebo byla skládána na základě oblíbeného bájesloví Rukopisů, ${ }^{7} \mathrm{u}$ žen se nově objevily pouze Božena a Růžena. I mezi chlapeckými „vlasteneckými“ jmény se na Novorychnovsku nejčastěji vyskytovala taková, která odkazovala na přijetí křestanství, například Bohumil. Není bez zajímavosti, že představitelé starší kněžské generace Jan Kalina (1854-1870) a jeho nástupce Václav Korál (1870-1877) tato jména bez problémů zapisovali do matrik, za jejich mladších kolegů se vlastenecké jméno v přibližně polovině př́ípadů uvádí v kombinaci s klasickým jménem katolického martyrologia, například Miloslav Václav nebo Bohuslav Jan.

$\mathrm{V}$ případě příchodu dcery ale mohli rodiče projevit vlastenecké smýšlení výběrem jména zcela v souladu s církevní tradicí. V roce 1859 se v Novém Rychnově narodila první Anežka, do počátku sedmdesátých let přibyly další trri, které do konce sledovaného období získaly osm desítek jmenovkyň; v devadesátých letech se jméno stalo dokonce třetím nejoblíbenějším. Za rychle rostoucí oblibou jména stálo blahořečení Anežky České v roce 1874, ačkoli od nepaměti bylo možné křtít na sv. Anežku Rímskou. Vlastenectví a katolickou víru podobně spojovalo jméno Ludmila, které se poprvé objevilo v kombinaci Ludmila Magdalena v roce 1875, aby koncem století svou oblibou zastínilo „barokní“ Kateřinu, Teresii či Antonii.

\section{Shrnutí: výsledky a perspektivy}

Nastíněné úvahy představují pouze zlomek poznatků k problematice rodinného života a každodenní kultury venkovské společnosti, které lze při detailním studiu čerpat z pramenů primárně evidujících přirozenou měnu obyvatelstva. Potvrzuje se, že užití kvantitativních metod může být přínosné i při sledování zdánlivě „nespočitatelných“ aspektů vývoje společnosti, jakým je náboženská praxe. Hlavním problémem použité metodiky je velká časová náročnost, která fakticky znemožňuje její uplatnění v širším čase a prostoru; přesná lokalizace a chronologické ukotvení zjištěných skutečností je však zároveň největší předností takto provedeného výzkumu oproti antropologicky zaměřenému bádání. Nutnou podmínkou pro zobecnění nabytých poznatků je však přihlédnutí k specifickým podmínkám Novorychnovska (relativně zaostalá venkovská oblast, př́tomnost církevní vrchnosti) a do budoucna i provedení komparativních sond do jiných sociálních prostředí. 
Představený výzkum potvrdil trvanlivost a pouze pomalou proměnu starší tradice okamžitého křtu novorozence. Křtiny byly na Novorychnovsku odkládány velmi opatrně, maximálně o několik dnů, i to ale značí změnu ve vnímání křestního obřadu, který zřejmě začínal směřovat k slavnostnějšímu, „rodinnému“ pojetí, jež se v měštanských vrstvách mělo začít prosazovat podstatně dříve (Alfani - Gourdon 2009). Tomu nasvědčuje i obliba nedělí jako křestních dnů. Podtrhnout je také třeba skutečnost, že odložené křty se častěji praktikovaly v rodinách žijících přímo v Novém Rychnově, v sousedních vsích se objevovaly méně, přestože návštěva kostela byla vzhledem $\mathrm{k}$ délce cesty komplikovanější. Zdá se tedy, že nový „trend“ vstupoval do menších vesnic pomaleji a rychleji se uchytil v městečku, třebaže by se rozdíl mezi těmito sídly mohl zdát vzhledem k počtu obyvatelstva a minimální vzdálenosti zanedbatelný.

Přetrvávající vliv katolických církevních tradic neukazuje jen načasování křestních obřadů, ale také trvalá obliba jmen v baroku preferovaných světců, z nichž pouze některá v druhé polovině 19. století nahradila jiná. Ukázalo se také, že zvyk pojmenovávat děti narozené před svátkem některého z významných svatých patronů „podle kalendáře“ přetrval v takřka neztenčené podobě do konce 19. století. Tradiční panteon světců a světic začala zároveň narušovat moderní a vlastenecká jména, která v př́ípadě chlapců odkazovala k staré slovanské tradici, zatímco u dívek se odvolávala na české katolické patronky Anežku a Ludmilu. Tento drobný rys může být jedním z dokladů odlišného pojetí náboženské víry a zbožnosti v případě žen (McLeod 2007: 142-153).

Trvalejší zachovávání starších tradic ženami je patrné i z delšího a intenzivnějšího udržování zvyku předávání křestních jmen v linii duchovního příbuzenství. Zatímco u chlapců byla zřejmě preferována rodová jména otců či dědečků, dívkám častěji dávala jméno kmotra. V obou případech se ale zdá, že právo pojmenovat novorozené dítě po sobě kmotři využívali převážně jen do poloviny 19. století, pozdější doklady jsou méně časté. Otázka preference rodových a kmotrovských jmen naznačuje další důležitou a náročnou etapu výzkumu, kterou bude třeba otevř́t, a tou je předpokládaná familiarizace kmotrovských vazeb, tedy jejich uzavírání dovnitř existujících rodinných struktur. Lze předpokládat, že zkoumání této problematiky může v budoucnu přinést řadu nových poznatků k dějinám a antropologii venkovské rodiny stejně jako k prožívání náboženské víry na venkově.

\section{Duben 2018}




\section{Literatura}

Alfani, Guido - Castagnetti, Philippe - Gourdon, Vincent (eds.). 2009. Baptiser. Pratique sacramentelle, pratique sociale (XVIe-XXe siècles).

Saint Étienne: Publications de l'université de Saint-Étienne.

Alfani, Guido - Goudon, Vincent - Robin, Isabelle (eds.). 2015. Le parrainage en Europe et en Amérique. Pratiques de longue durée XVIe-XXIe siècles. Bruxelles: Peter Lang.

Alfani, Guido - Gourdon, Vincent - Vitali, Agnese. 2011. Social Customs and Demographic Change: The Case of Godparenthood in Catholic Europe. Milan: Dondena Working Papers.

Alfani, Quido - Gourdon, Vincent. 2009. Fêtes du baptême et publicité des réseaux sociaux en Europe Occidantale. Grandes tendances de la fin du Moyen Âge au XXe siècle. Annales de démographie historique 117: 153-189.

Arrizabalaga, Marie-Pierre. 2016. Le choix des prénoms des français en Californie intérieure (1880-1940): Étude d'un processus d'acculturation dans une approche genrée: Annales de démographie historique 131: 97-130.

Bělík, Václav. 1946. Úvod a úvodky na Českomoravské vysočině. In: Sborník Vysočina. František Zvěřina (ed.) Praha: Vysočina: 70-73.

Boulton, Jeremy. 1989. Economy of time? Wedding days and working week in the past? Local population studies 43: 28-46.

Cílek, Václav - Svoboda, Jiří - Vašků, Zdeněk. 2003. Velká kniha o klimatu zemí Koruny české. Praha: Regia.

Coulmont, Baptiste. 2016. Des prénoms qui ont du chien: le partage des prénoms entre hommes et chiens: Annales de démographie historique 131: 151-170.

Dalla-Zuanna, Gianpeiro - Minello, Alessandra - Piccione, Leonardo. 2017. Sweet Child of mine. Child Mortality in Veneto at the Dawn of the Demographic Transition. Padova: CLEUP.

Dokoupil, Lumír - Nesládková, Ludmila. 1987a. Úmrtnost kojenců a mladších dětí v českých zemích na sklonku feudalismu. Historická demografie 11: 141-158.

Dokoupil, Lumír - Nesládková, Ludmila. 1987b. Charakteristické rysy vývoje úmrtnosti obyvatelstva českých zemí v 19. století. Historická demografie 12: 193-206.

Ducreux, Marie-Elizabeth. 2006. Několik úvah o barokní zbožnosti a o rekatolizaci Čech. Folia historica Bohemica 22: 143-177.

Dupâquier, Jacques. 1981. Naming-practices, Godparenthood, and Kinship in the Vexin, 1540-1900. Journal of Family History 6: 135-155.

Ericsson, Tom. 2000. Godparents, Witnesses, and Social Class in Midnineteenth Century Sweden. The history of the Family 5: 273-286.

Fertig, Christine. 2009. Rural Society and Social Networks in Nineteenthcentury Westphalia: The Role of Godparenting in Social Mobility. Journal of Interdisciplinary History 39: 497-522.

Gélis, Jacques. 1984. L'arbre et le fruit. La naissance dans I'Occident moderne, XVIe-XIXe siècle. Paris: Fayard.

Gennep, Arnold van. 1998. Le Folklore français. Du berceau á la tombe. Cycles de Carnaval-Carême et de Pâques. Paris: Bouquins.

Gourdon, Vincent. 2006. Les pratiques du baptême à Paris et à Rome au XIXe siècle. Popolazione e Storia 2: 19-60.

Grulich, Josef. 2000. „Slavnostní okamžiky“ - svatební a křestní obřad v období raného novověku. (Závěry tridentského koncilu a pražské synody ve světle jihočeských matričních zápisů z 2. poloviny 17. století. Historická demografie 24: 49-82. 
Hofmann, Gustav. 1968. Vývoj křestních jmen na Ptenínsku v letech 1651-1921. Zpravodaj místopisné komise ČSAV 9: 337-350.

Horská, Pavla. 1972. Historický vývoj plodnosti v českých zemích. Stav a možnosti výzkumu. Historická demografie 6: 3-39.

Jílek, František. 1961. Jihočeský člověk a jeho řeč. České Budějovice: Krajské nakladatelství České Budějovice.

Knappová, Miloslava. 1978. Jak se bude jmenovat? Praha: Academia.

Knappová, Miloslava. 2017. Jak se bude Vaše dítě jmenovat? Praha: Academia (6. vydání).

Kovářová, Marie. 1972. Z lidových zvyků Podblanicka. Narození dítěte - v šestinedělí

- křest a úvod. Sborník vlastivědných prací z Podblanicka 13: 192-217.

Maur, Eduard. 2008. Přehled vývoje české historické demografie. Demografie 50: 268-275.

McLeod, Hugh. 2000. Sekularizace v západní Evropě (1848-1914).

Brno: Centrum pro studium demokracie a kultury.

McLeod, Hugh. 2007. Náboženství a lidé západní Evropy (1789-1989).

Brno: Centrum pro studium demokracie a kultury.

Melkesová, Miroslava. 2003. Adhiberi solent, qui compatres vocantur. Kmotrovství ve venkovském prostředí raného novověku na základě výzkumu chýnovské matriky. Historická demografie 27: 63-120.

Mužík, Petr. 1979. Vývoj křestních jmen v Domažlicích v letech 1631-1830. Zpravodaj místopisné komise ČSAV 20: 530-553.

Navrátilová, Alexandra. 1984. K analýze tendencí vývoje rodinných obřadů na současné vesnici. Obřady spojené s narozením. Český lid 71: 29-36.

Navrátilová, Alexandra. 2004. Narození a smrt v české lidové kultuře. Praha: Vyšehrad.

Nekvapil, Ladislav. 2011. Kmotrovské vazby ve farnosti Hlinsko v letech 1645-1650 z hlediska sociálně-náboženského (sonda). Historická demografie 35: 33-44.

Nešpor, Zdeněk R. 2006. Náboženství na prahu nové doby. Česká lidová zbožnost 18. a 19. století. Ústí nad Labem: Albis international.

Pauly, Jan. 1902. Právní rádce pro duchovní správu v Čechách, na Moravě a ve Slezsku. Systematický soubor církevních a státních zákonů, nařizení, rozhodnutí, norem a př́slušných formulářu s praktickým návodem pro duchovní správu. Praha.

Quemener, Pierre-Yves. 2017. Parrainage et nomination en Bretagne aux XVe et XVIe siècles. Annales de demographie historique 133: 145-179.

Skořepová, Markéta. 2016a. Kmotrovství jako badatelský problém. K sociálním dějinám raného novověku a 19. století. Český časopis historický 114: 58-82.

Skořepová, Markéta. 2016b. Ovdovění a osiření ve venkovské společnosti. Panství Nový Rychnov, 1785-1855. České Budějovice: Jihočeská univerzita v Českých Budějovicích.

Skořepová, Markéta. 2016c. Poručníci, kmotři a zástupci osiřelých dětí ve venkovské společnosti první poloviny 19. století. Opera Historica 17: 69-84.

Skořepová, Markéta. 2018. Křty a kmotrovství ve farnosti Nový Rychnov v 19. století. Historická demografie 42: 43-64.

Stoklasová, Hana. 2017. Katolické přechodové rituály v "dlouhém" 19. století. Pardubice: Univerzita Pardubice.

Violić-Koprivec, Ariana - Vekarić, Nenad. 2017. Baptism and marriage witnesses of the Cathilics of Dubrovnik (1870-1871). Dubrovnik Annals 21: 97-137.

Vlčková, Michaela. 2015. Žehnání matky. Význam obřadu v Čechách a na Moravě v 16.-21. století. Praha: Akropolis.

Vovelle, Michel. 1973. Piété baroque et déchristianisation en Provence au XVIIIe siècle. Paris: Plon. 


\section{Prameny}

SOA Třeboň, SMJK, FÚ Nový Rychnov: Státní oblastní archiv Třeboň, Sbírka matrik Jihočeského kraje, Farní úřad Nový Rychnov, kniha č. 1 [matrika NOZ Nový Rychnov 1785-1815];

kniha č. 3 [NOZ Dolní Hutě 1785-1815];

kniha č. 4 [NOZ Hojkov 1785-1815];

kniha č. 5 [NOZ Chaloupky 1785-1815];

kniha č. 8 [NOZ Milíčov 1785-1815];

kniha č. 13 [N farnost Nový Rychnov 1815-1848];

kniha č. 14 [N farnost Nový Rychnov 1848-1863];

kniha č. 15 [N farnost Nový Rychnov 1864-1877];

kniha č. 16 [N farnost Nový Rychnov 1878-1888];

kniha č. 17 [N farnost Nový Rychnov 1888-1899];

kniha č. 18 [N farnost Nový Rychnov 1899-1912].

Národní archiv Praha, Stabilní katastr-duplikát, inv. č. 8661, kar. 3861.

Hille, Jan Pavel. 1895. Farní osada Novo-rychnovská v Táborsku.

Náčrtek historicko-místopisný. Praha.

Schaller, Jaroslav. 1790. Topographie des Königreichs Böhmen XIV. Taborer Kreis.

Sommer, Johann Gottfried. 1842. Das Königreich Böhmen. Taborer Kreis.

Trajer, Johann. 1862. Historisch-statistische Beschreibung der Diöcese Budweis, Budweis. Historický lexikon obcí České republiky 1869-2005 I. 2006. Praha: Český statistický úřad. www.dondena.unibocconi.it/patrinus. 